\title{
17. AGE OF HYDROTHERMAL CIRCULATION ON THE RIO GRANDE RISE: DEEP SEA DRILLING PROJECT SITE 516 1
}

\author{
Stanley R. Hart, Center for Geoalchemy, Department of Earth \& Planetary Sciences, \\ Massachusetts Institute of Technology, Cambridge, Massachusetts \\ and \\ Hubert Staudigel, Lamont-Doherty Geological Observatory of Columbia University, Palisades, New York
}

\begin{abstract}
A well-constrained $\mathrm{Rb} / \mathrm{Sr}$ isochron of secondary celadonites and carbonate from DSDP Hole 516F yields an age of $70.1 \pm 1.6 \mathrm{Ma}$. This age is younger than the age of crust formation (about $82 \mathrm{Ma}$ ) and may provide evidence for a shortlived hydrothermal event on the Rio Grande Rise caused by a phase of off-ridge volcanism. The initial ${ }^{87} \mathrm{Sr} /{ }^{86} \mathrm{Sr}$ ratios of the celandonites and carbonate are lower than the contemporaneous seawater and indicate that the dissolved load of the hydrous solutions contains approximately $2 \%$ of basaltic component. $\mathrm{K}, \mathrm{Rb}$, and Cs contents in Hole $516 \mathrm{~F}$ celadonites are similar to corresponding phases from DSDP Hole 417A, indicating that the upper crust at this site may represent a significant sink for seawater alkalies. The alkali ratios $\mathrm{K} / \mathrm{Rb}$ and $\mathrm{K} / \mathrm{Cs}$ of Hole $516 \mathrm{~F}$ celadonites are also similar to the ratios in celadonites from 108-Ma-old crust at DSDP Holes 417 and 418 . This correspondence shows that the K/ $\mathrm{Rb}$ and $\mathrm{K} / \mathrm{Cs}$ ratios in seawater remained essentially constant during the Cretaceous, from 108 to $70 \mathrm{Ma}$.
\end{abstract}

\section{INTRODUCTION}

Site 516 of the Deep Sea Drilling Project (DSDP) was drilled near the crest of the Rio Grande Rise (Fig. 1). Based on the magnetic anomaly pattern of the surroundng ocean floor, the oceanic crust at this site was formed during the Santonian/Coniacian, approximately $82 \mathrm{Ma}$ (LaBrecque et al., 1977). This age is probably correct within a few million years, but individual age constraints from magnetic anomaly patterns, fossil faunas, magnetostratigraphy, and ${ }^{39} \mathrm{Ar} /{ }^{40} \mathrm{Ar}$ studies are not well constrained (Cande and Rabinowitz, 1979; Weiss, this volume; Mussett and Barker, this volume; Berggren et al., this volume). However, all evidences combined support this age quite well, indicating that basalts at Site 516 were formed on the Mid-Atlantic Ridge. The oceanic crust at this site was formed in very shallow water and subsided significantly after its formation (Barker et al., 1981; Barker, this volume). Volcanic activity resumed during subsidence, as documented by a volcanic debris flow during the Eocene at DSDP Site 357 (Fodor and Thiede, 1977) and various ash layers throughout the core of Hole $516 \mathrm{~F}$.

Basalts from Hole $516 \mathrm{~F}$ are altered and contain abundant veins with secondary phases deposited by circulating hydrous solutions. For this chapter, we have determined the depositional ages of these veins. In "normal" oceanic crust, significant hydrothermal systems develop only near the ridge crest (e.g., Elder, 1965; Anderson et al., 1977; Wolery and Sleep, 1976). Such hydrothermal systems are very short-lived, and secondary phases deposited by these systems were successfully used to constrain basement ages (Hart and Staudigel, 1978; Richardson et al., 1980). Seamounts or aseismic

\footnotetext{
${ }^{1}$ Barker, P. F., Carlson, R. L., Johnson, D. A., et al., Init. Repts. DSDP, 72: Washington (U.S. Govt. Printing Office).
}

ridges such as the Rio Grande Rise, however, are characterized by off-ridge volcanism which is probably also accompanied by the development of hydrothermal systems. Vein minerals deposited from such hydrothermal systems may not constrain the original basement formation age, but they may provide age constraints for phases of off-ridge volcanism.

\section{ANALYTICAL METHODS}

We selected celadonite veins and a coexisting carbonate for $\mathrm{Rb}-\mathrm{Sr}$ age determination. Phases were identified using X-ray powder methods and a Grandolfi camera. After crushing to a grain size of approximately 30 to $100 \mu \mathrm{m}$, the samples were briefly washed in distilled water to reduce any seawater contamination which occurred during drilling and recovery of the cores. Hand-picked mineral separates were ground in an agate mortar and analyzed for $\mathrm{K}, \mathrm{Rb}, \mathrm{Cs}, \mathrm{Sr}$, and ${ }^{87} \mathrm{Sr} / 86 \mathrm{Sr}$ using the methods of Hart and Brooks (1974). Phase identification and analytical data are listed in Table 1.

\section{VEIN MINERAL DEPOSITION AT SITE 516}

$\mathrm{Rb} / \mathrm{Sr}$ and ${ }^{87} \mathrm{Sr} / 86 \mathrm{Sr}$ data are plotted on an isochron diagram, Figure 2 , and the best-fit age for all data is $70.1 \pm 1.6 \mathrm{Ma}$. Note that this age is strongly controlled by the high $\mathrm{Rb} / \mathrm{Sr}$ sample \#1. If this sample is excluded from the isochron regression, the age increases to 73.7 $\pm 2.6 \mathrm{Ma}$; this age has a significantly larger uncertainty as a result of the smaller spread in the $\mathrm{Rb} / \mathrm{Sr}$ ratio, but overlaps, within errors, the $70.1 \mathrm{Ma}$ age derived using all of the data. We have shown previously (Hart and Staudigel, 1978) that clay mineral and carbonate alteration phases in ocean crust generally have different initial $\mathrm{Sr}$ isotopic ratios, and thus it may not be appropriate to include the calcite sample (\#6) in the age regression. If the calcite is excluded, regression of the celadonite samples alone gives an age of $69.7 \pm 1.8 \mathrm{Ma}$, not significantly different from the age derived with the calcite included.

$\mathrm{The} \mathrm{Rb} / \mathrm{Sr}$ age of these Hole $516 \mathrm{~F}$ alteration phases is significantly younger than the presumed $82 \mathrm{Ma}$ age of 


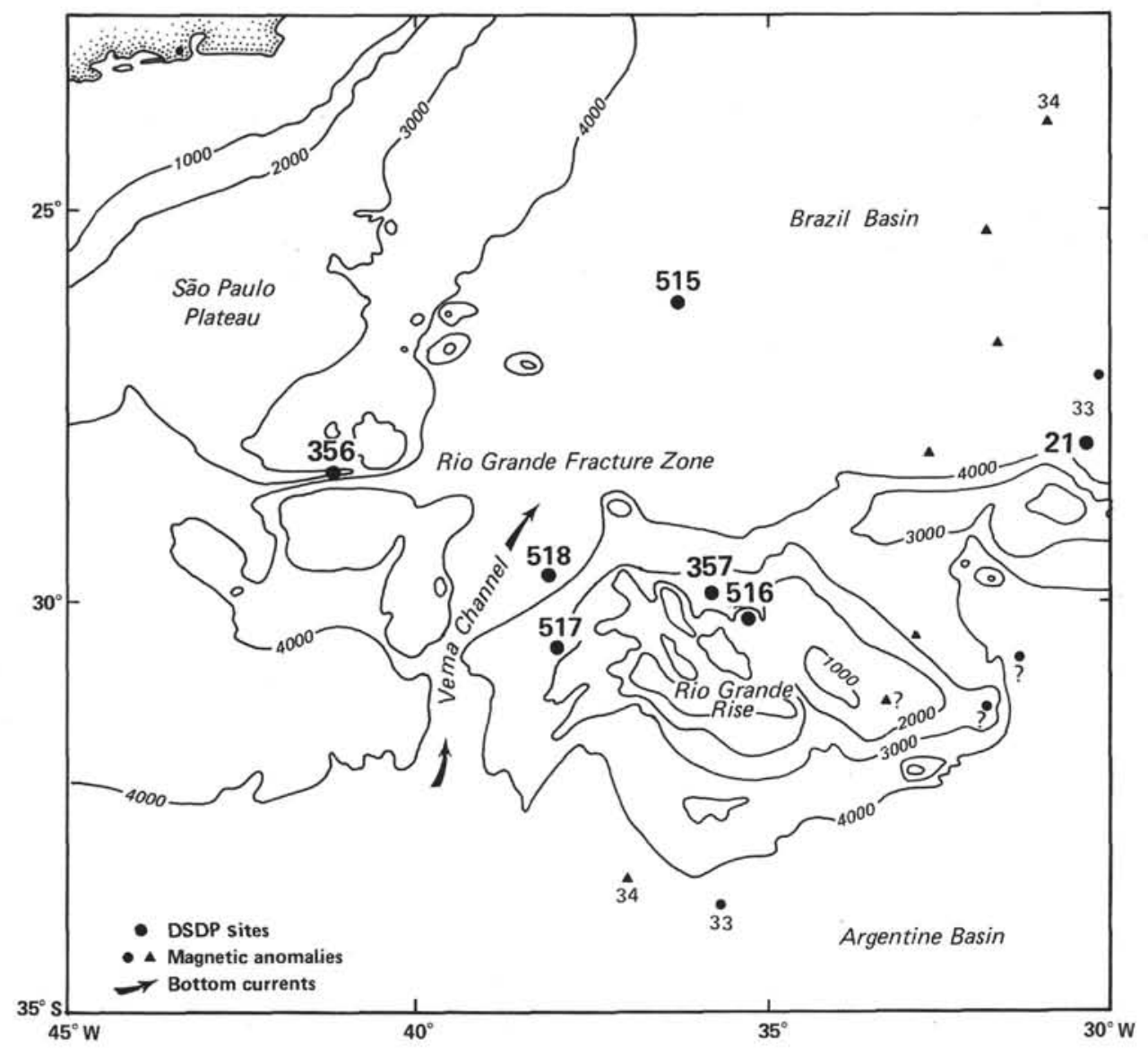

Figure 1. Location of DSDP Site 516 on the Rio Grande Rise. The location of magnetic anomalies according to Cande and Rabinowitz (1979) is indicated.

Table 1. K, Rb, Cs, Sr, and ${ }^{87} \mathrm{Sr} /{ }^{86} \mathrm{Sr}$ in vein materials from DSDP Hole $516 \mathrm{~F}$, Leg 72.

\begin{tabular}{|c|c|c|c|c|c|c|c|c|}
\hline No. & $\begin{array}{l}\text { Core-section } \\
\text { interval in } \mathrm{cm} \\
\text { (piece number) }\end{array}$ & Description & $\begin{array}{l}\text { Sub-basement } \\
\text { depth } \\
\text { (m) }\end{array}$ & $\underset{(\%)}{K}$ & $\underset{(\mathrm{ppm})}{\mathrm{Rb}}$ & $\underset{(\mathrm{ppm})}{\mathrm{Cs}}$ & $\begin{array}{c}\mathrm{Sr} \\
\text { (ppm) }\end{array}$ & ${ }^{87} \mathrm{Sr} /{ }^{86} \mathrm{Sr}^{\mathrm{a}}$ \\
\hline 1 & $126-3,135-140(\# 5 d)$ & Celadonite & 4.6 & 4.140 & 171.6 & 1.41 & 26.64 & $0.72520 \pm 5$ \\
\hline 2 & $126-3,86-88(\# 4 a)$ & Celadonite-smectite mix & 4.1 & 2.249 & 84.51 & 0.604 & 64.23 & $0.71094 \pm 5$ \\
\hline 3 & $126-4,22-25(\# 2 b)$ & Celadonite & 4.9 & 3.702 & 132.4 & 0.892 & 93.25 & $0.71121 \pm 5$ \\
\hline 4 & $126-3,47-51(\# 2 f)$ & Celadonite & 3.7 & 3.893 & 139.9 & 0.931 & 95.03 & $0.71127 \pm 5$ \\
\hline 5 & $126-4,15-18(\# 2 a)$ & Celadonite-smectite mix & 4.8 & 1.746 & 67.82 & 0.746 & 191.2 & $0.70786 \pm 4$ \\
\hline 6 & $126-4,15-18(\# 2 d)$ & Calcite & 4.8 & $9.68(\mathrm{ppm})$ & 0.0370 & 0.0052 & 87.79 & $0.70694 \pm 15$ \\
\hline
\end{tabular}

a Data relative to 0.70800 for $\mathrm{E} \& \mathrm{~A}$ standard; errors refer to last significant digits and are 20 in-run statistics.

basement formation. Either the hydrothermal activity associated with basement formation persisted for some 10 to $15 \mathrm{Ma}$, or these alteration phases were deposited during a second hydrothermal "event" which postdated basement formation by 10 to $15 \mathrm{Ma}$. Evidence for later phases of off-ridge igneous activity is found in the occurrences of volcanic ash layers in the sediment section at Site 516 and nearby DSDP sites. An Eocene volcanic debris flow is reported from Site 357 (fig. 1; Fodor and Thiede, 1977). Eocene igneous activity is also indicated by abundant ash layers in Cores $516 \mathrm{~F}-40$ to 83 . Furthermore, ash layers are not restricted to the Eocene; there are more than $10 \%$ ash particles in smear slides from Cores 96, 114, and 124 (Site 516 chapter, this volume). Sediments of Core 96 were deposited during the early/middle Maestrichtian, corresponding to an age of about $70 \mathrm{Ma}$, similar to the $\mathrm{Rb} / \mathrm{Sr}$ age of alteration phases reported above.

The initial ${ }^{87} \mathrm{Sr} /{ }^{86} \mathrm{Sr}$ ratio of the $\mathrm{Rb} / \mathrm{Sr}$ isochron (all samples) is $0.70699 \pm 10$. If the calcite sample is excluded, the initial ratio increases slightly to $0.70702 \pm$ 12. While many of the samples do not fit the isochron within experimental error (in terms of ${ }^{87} \mathrm{Sr} /{ }^{86} \mathrm{Sr}$ ), the maximum deviation from the isochron is only $0.02 \%$, suggesting that, to first order, all of these phases were deposited from hydrous solutions with very similar $\mathrm{Sr}$ isotopic composition. This uniformity is in marked contrast to the situation found for alteration phases formed during crust-formation processes on the Mid-Atlantic Ridge. Layer silicates from Holes 332B, 417A, 417D, and $418 \mathrm{~A}$ show a large spread in initial $\mathrm{Sr}$ isotopic composition, with values always lower than the contem- 


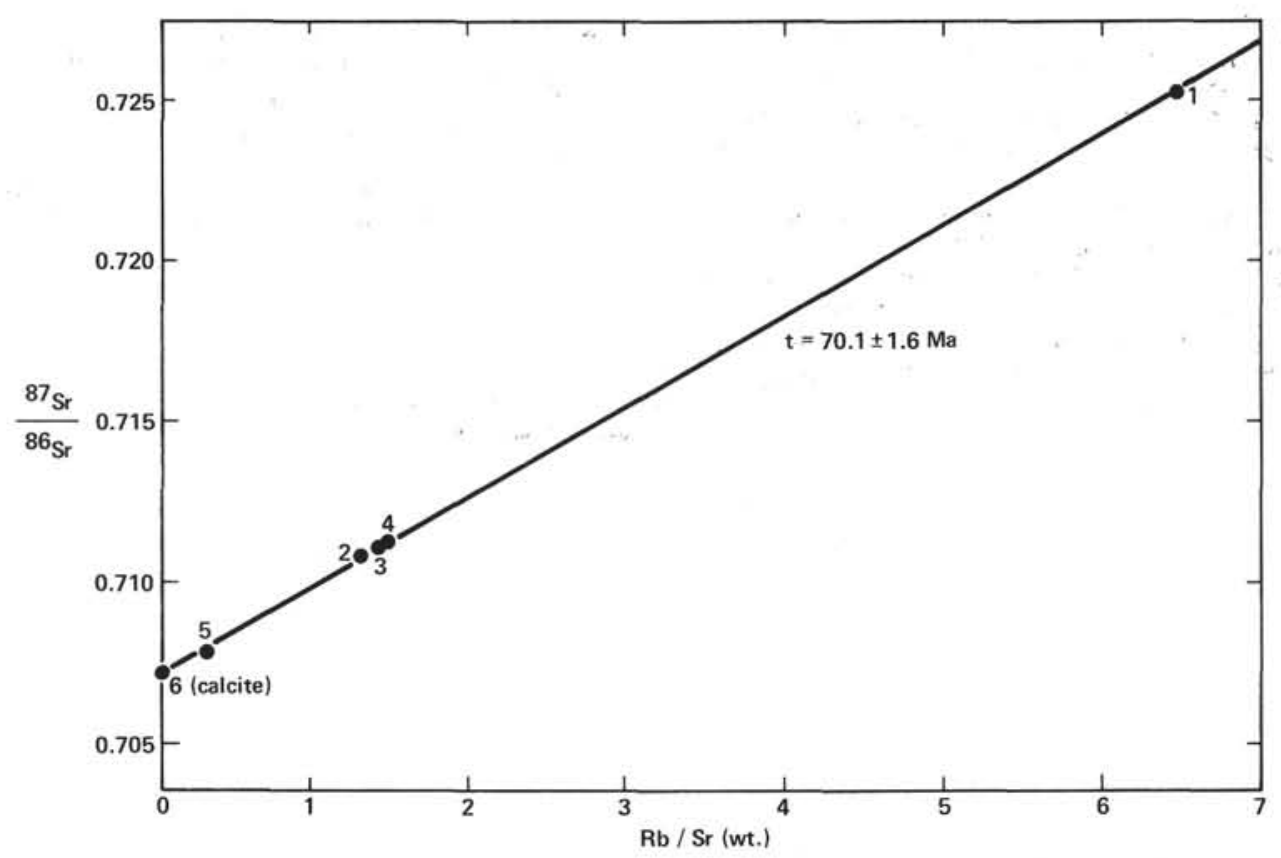

Figure 2. Rb-Sr isochron plot for secondary phases (celadonites and calcite) from DSDP Hole 516F. Data are from Table 1.

poraneous seawater. Carbonates from these same sites, however, show isotopic compositions similar or identical to the ambient seawater (Hart and Staudigel, 1978; Richardson et al., 1980; Staudigel et al., 1981). At Site 516 , the calcite and celadonites have similar initial $\mathrm{Sr}$

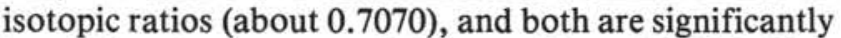
lower than the seawater of that age (about 0.70780; Hart and Staudigel, 1978). Thus both the calcite and the celadonites were deposited from solutions which represent mixtures of about $2 \%$ basalt $\left(100 \mathrm{ppm} \mathrm{Sr} ;{ }^{87} \mathrm{Sr} /{ }^{86} \mathrm{Sr}=\right.$ $0.703-0.705)$ and $98 \%$ seawater $\left(8 \mathrm{ppm} ;{ }^{87} \mathrm{Sr} /{ }^{86} \mathrm{Sr}=\right.$ 0.7078 ).

As discussed by Staudigel and others (1981), seawater solutions which have hydrothermally interacted with basaltic crust will have lower $\mathrm{Sr} / \mathrm{Ca}$ ratios than pure seawater, and this will be reflected in low Sr contents in precipitated carbonates. The Sr content of the Hole $516 \mathrm{~F}$ calcite $(88 \mathrm{ppm})$ is considerably lower than that expected for calcite precipitation from seawater (about $500 \mathrm{ppm}$ ), suggesting that the initial Sr ratio of this calcite was lower (more basaltic) than 70-Ma-old seawater. In other words, the Hole $516 \mathrm{~F}$ carbonate reflects a hydrothermal system of lower water/rock ratio than that reflected by carbonate phases deposited during normal crust-formation processes. This contrast is most simply explained if the alteration of these rocks occurred in response to an off-ridge volcanic episode, at a time when some $200 \mathrm{~m}$ of sediment were already deposited, inhibiting communication between seawater and the hydrothermal circulation in the crust.

The layer silicates analyzed from Hole $516 \mathrm{~F}$ have high $\mathrm{K}, \mathrm{Rb}$, and $\mathrm{Cs}$ contents, indicative of a large proportion of celadonite in these separates. In this respect, these samples are similar to the layer-silicates analyzed from Hole 417A (Staudigel et al., 1981), and further document the concept that the oceanic crust is a very efficient sink for seawater-derived alkalies (Hart and Staudigel, 1982). The K/Rb and K/Cs ratios of the Hole $516 \mathrm{~F}$ celadonites are also very similar to the values in celadonites and analcites from Sites 417 and $418(\mathrm{~K} /$ $\mathrm{Rb}=264$ versus 276 , and $\mathrm{K} / \mathrm{Cs}=34700$ versus 32800 ). These ratios are dominantly controlled by the alkali abundances of ambient seawater (the basalt "component" in these minerals is limited to about $2 \%$ based on the $\left.{ }^{87} \mathrm{Sr} /{ }^{86} \mathrm{data}\right)$, suggesting that alkali ratios in seawater have remained essentially constant from $108 \mathrm{Ma}$ (Sites 417 and 418 ) to $70 \mathrm{Ma}$ (Hole 416F).

\section{ACKNOWLEDGMENTS}

We acknowledge financial support from the Office of Naval Research (Contract \#N0001-75-C-0291) and the National Science Foundation (Grant \#OCE 79-09457) to S. R. Hart, and from the LamontDoherty Geological Observatory of Columbia University. Samples were obtained through the NSF/Deep Sea Drilling Project. This paper benefited from collaboration with D. Johnson and A. Shor. This is LDGO Contribution \#3487.

\section{REFERENCES}

Anderson, R. N., Langseth, M. G., and Sclater, J. G., 1977. Hydrothermal circulation and geochemical flux at mid-ocean ridges. $J$. Geophys. Res., 82:3391-1409.

Barker, P. F., Carlson, R. L., Johnson, D. A., Čepek, P., Coulbourn, W., Gamboa, L. A., Hamilton, N., Melo, U., Pujol, C., Shor, A., Suzyumov, A. E., Tjalsma, L. R. C., Walton, W. H., and Weis, W., 1981. Deep Sea Drilling Project Leg 72: Southwest Atlantic Paleocirculation and Rio Grande Rise Tectonics. Geol. Soc. Am. Bull., 92:294-309.

Cande, S. C., and Rabinowitz, P., 1979. Magnetic anomalies of the continental margin off Brazil. Am. Assoc. Pet. Geol. Map Ser.

Elder, J. W., 1965. Physical processes in geothermal areas. In Lee, W. H. K. (Ed.), Terrestrial Heat Flow. Am. Geophys. Union Monogr., 8:211-239.

Fodor, R. V., and Thiede, J., 1977. Volcanic breccia from DSDP Site 357: Implications for the composition and origin of the Rio 
Grande Rise, South Atlantic Ocean. In Supko, P. R., PerchNielsen, K., et al., Init. Repts. DSDP, 39: Washington (U.S. Govt. Printing Office), 537-543.

Hart, S. R., and Brooks, C., 1974. Clinopyroxene-matrix partitioning of $\mathrm{K}, \mathrm{Rb}, \mathrm{Cs}, \mathrm{Sr}$ and $\mathrm{Ba}$. Geochem. Cosmochim. Acta, 38: 1799-1806.

Hart, S. R., and Staudigel, H., 1978. Oceanic crust: Age of hydrothermal alteration. Geophys. Res. Lett., 5:1009-1012. ,1982. The control of alkalies and uranium in sea water by ocean crust alteration. Earth Planet. Sci. Lett., 58:202-212.

LaBrecque, J. L., Kent, D. V., and Cande, S. C., 1977. Revised magnetic polarity time scale for Late Cretaceous time. Geology, 5: 330-335.
Richardson, S. H., Hart, S. R., and Staudigel, H., 1980. Vein mineral ages of old oceanic crust. J. Geophys. Res., 85:7195-7200.

Staudigel, H., Hart, S. R., and Richardson, S., 1981. Alteration of the oceanic crust: Processes and timing. Earth Planet. Sci. Lett., 52:311-327.

Wolery, T. J., and Sleep, N., 1976. Hydrothermal circulation and geochemical flux at mid ocean ridges. J. Geol., 84:249-276.

Date of Initial Receipt: August 19, 1982 